\title{
II. COMÉRCIO INTERNACIONAL E SAÚDE PÚBLICA
}

PROCESSO N. 98.0011692-3

MANDADO DE SEGURANÇA

IMPTE: DIGIENE DO BRASIL LTDA.

IMPTO: INSPETOR DA RECEITA FEDERAL NO AEROPORTO INTERNACIONAL DE SÃO PAULO - GUARULHOS

14늘 VARA

Vistos.

1. Recebo a petição de fls. $59 / 115$ como aditamento da inicial. Oportunamente, à SUDI para retificar o pólo passivo.

2. Verifico a presença dos pressupostos legais necessários à concessão liminar da medida. A plausibilidade do direito invocado exsurge, inicialmente, do fato de que o Comunicado DECEX n. $37 / 97$ não impõe a exigência de termo de liberação do Serviço de Vigilância Sanitária para o desembaraço do produto importado pela impetrante - 100 (cem) unidades de "kits" para Captura Híbrida para o HPV (fls. 68) - cujo licenciamento já foi obtido junto ao DECEX (fls. 56). Outrossim, a Portaria n. 54/97, do Sr. Secretário de Vigilância Sanitária do Ministério da Saúde, não parece incluir o aludido produto importado dentre aqueles em relação aos quais está mantida a exigência de anuência prévia do Ministério da Saúde (fls. 69).

3. O periculum in mora, por sua vez, decorre da possibilidade de a impetrante vir a experimentar sérios prejuizos em suas atividades, em virtude da interrupção do desembaraço aduaneiro em tela, fazendo com que a eventual concesão da medida requerida, apenas a final, posa resultar na ineficiência. 
4. Isto posto, DEFIRO A LIMINAR para o fim de determinar, ao impetrado, que promova o desembaraço aduaneiro referente à importação das 100 (cem) unidades de "kits" para a Captura Hídrida para o HPV, aos quais se refere a Autorização de Importação n. 200.98/0008-5, consoante os documentos juntados aos autos. Indefiro o pedido formulado na alínea "c", do item 3.1, da inicial (fls. 14), por conferir caráter normativo ao mandamus.

5. Notifique-se ao impetrado para a prestação de informações, no prazo legal.

6. Após, ao Ministério Público Federal.

São Paulo, 23 de março de 1998.

Regina Helena Costa

Juiza Federal

\section{COMENTÁRIOS}

Deisy de Freitas Lima Ventura ${ }^{(*)}$

O objeto da decisão judicial em tela é o desembaraço aduaneiro de um lote de testes clínicos para o diagnóstico de câncer do colo uterino. Esses testes consistem na deteç̧ão do DNA do Papilomavirus Humano - HPV, reputado como o agente causador do referido tipo de câncer, pelo que são comercialmente conhecidos como "kits" de Captura Hibrida para o HPV.

A decisão concede liminar em mandado de segurança - cujo julgamento de mérito está ainda pendente - impetrado pela Digene do Brasil Ltda. contra o Inspetor da Alfândega no Aeroporto Internacional de São Paulo (Guarulhos).

Alegou a Impetrante que possui o direito líquido e certo de importar os kits de Captura Híbrida para o HPV. Com efeito, embora já habitual por parte da Impetrante, a importação foi obstaculizada pela autoridade coatora, que interrompeu o despacho aduaneiro ordinário, ao exigir a apresentação, pela Impetrante, de um termo de liberação do Serviço de Vigilância Sanitária do Ministério da Saúde para desembaraço dos testes.

Em outras palavras, a jurisdição foi provocada a responder à questão: é necessária a anuência prévia do Ministério da Saúde para a importação desses kits ? Como segunda questão, relativa ao caráter cautelar do pedido, instou-se o magistrado a verificar a existência, no caso concreto, de um di-

(*) Professora do Curso de Direito e do Mestrado em Integração Latino-americana da Universidade Federal de Santa Maria; DEA Direito Comunitário e Europeu da Universidade de Paris I, PanthéonSorbonne. 
reito líquido certo, além da habitual aferição do fumus boni juris e do periculum in mora que devem justificar o pedido in limine.

No que concerne à primeira questão, o.reconhecimento do direito da Impetrante afigurava-se indispensável não somente pelo conteúdo da decisão, mas também para o cabimento de ação, com certeza uma das mais fortes armas procedimentais do direito. Medida típica para correção da conduta administrativa do Estado, o mandado de segurança visa, no caso concreto, a proteger um direito líquido e certo que uma autoridade pública, diretamente ou por via de delegação, viola ou ameaça violar. Nas palavras de Celso Antônio Bandeira de Mello,

"considera-se líquido e certo o direito, independentemente de sua complexidade, quando os fatos a que se deva aplicá-lo sejam demonstráveis de plano; é dizer, quando independam de instrução probatória"(1).

Assim, a jurisdição considerou desnecessária a prévia anuência do Serviço de Vigilância Sanitária, reconhecendo assim o direito de importação à Digene do Brasil. Com efeito, a Impetrante demonstrou que nem o direito aduaneiro, tampouco a legislação sanitária, dão amparo à exigibilidade de prévia manifestação do Serviço de Vigilância Sanitária.

No que se refere ao direito aduaneiro, estava em questão o Comunicado DECEX n. 37/97, uma das peças centrais da implantação do recente Sistema Integrado de Comércio Exterior - SISCOMEX. Deve-se reconhecer que a implantação do novo sistema gerou inúmeros problemas de adaptação nas aduanas, eis que, ao substituir as guias de importação de produtos por mero registro através de um sistema informatizado, inverteu a regra de exigência de licenciamentos para importação. Desse modo, a necessidade de licenciamento prévio passou a configurar uma exceção, e não a regra.

O SISCOMEX foi objeto, aliás, da primeira decisão arbitral proferida no âmbito do Mercado Comum do Sul - Mercosul, bloco econômico formado por Argentina, Brasil, Paraguai e Uruguai desde 1991. (2) Naquela ocasião, - Brasil foi condenado por um Tribunal Arbitral ad hoc por ter, através do novo sistema, incluído novas exigências restritivas de comércio entre os Estados-membros do bloco. ${ }^{(3)}$ Não se trata do mesmo caso dos kits para captu-

(1) Celso Antônio Bandeira de Mello, "Curso de Direito Administrativo". São Paulo: Malheiros, 2000, pp. 214-215.

(2) Mercosul, "Controvérsia sobre os Comunicados n. 37 de 17/12/1999 e n. 7 de 20/02/1998 do DECEX: Aplicação de Medidas Restritivas do Comércio Recíproco". Disponivel em: <http:// www.mercosur.org.uy/espanol/snor/normativa/laudos.htm/s.

(3) Sobre a primeira decisão arbitral do Mercosul, ver Deisy Ventura, "First arbitration award in Mercosur - a community law in evolution". In Leiden Journal of International Law, v.13, n. 2, 2000, pp. 447-458. 
ra do HPV, eis que a própria regulamentação do SISCOMEX dispensava a exigência feita pela aduana de São Paulo.

A Impetrada, a autoridade aduaneira paulista, também não encontrou fundamento para seu gesto na legislação sanitária em vigor, pois a Portaria da Secretaria de Vigilância Sanitária n. 54, de 14/1/1997, isenta igualmente a importação dos testes da necessidade de prévia anuência do Ministério da Saúde.

Ressalte-se que, sob o prisma da saúde pública, causa espécie que a importação em tela pudesse ser interrompida no momento em que o próprio governo brasileiro desenvolvia dois programas de prevenção ao câncer do colo do útero. Encontravam-se já em andamento o projeto "Diagnóstico Molecular do Câncer do Colo do Útero", no Ministério da Ciência e da Tecnologia, além do Programa do próprio Ministério da Saúde, denominado "Viva Mulher", realizado através do Instituto Nacional do Câncer.

Não há dúvida de que a aduana não dispõe de competência material ou formal para constituir novas exigências, à margem da lei, que dificultem a importação de produtos. Mas essa usurpação de poder regulamentar é ainda mais grave quando se está diante de um imperativo sanitário, eis que a importação do lote em questão fazia parte de uma política pública de saúde.

Responde-se, assim, à segunda questão a desafiar o magistrado, que aqui identificou precisamente o caso de periculum in mora. Ou seja, o fato de que, negada a liminar, mesmo posteriormente deferido o mérito da ação, a sentença poderia mostrar-se ineficaz. Ora, na situação fática em apreciação, a posterior reparação pela exigência ilicita seria inútil diante do número de pessoas prejudicadas pela não aplicação dos testes:

"É injurídico entender-se ausente o pressuposto do periculum in mora para concessão de liminar em sede de mandado de segurança, sob o argumento de que a efetiva lesão do bem jurídico comporta reparação patrimonial (rectius: solução em perdas e danos), porque, como queremos acentuar, a natureza desta ação de segurança é a prestação do bem jurídico in natura, nunca pelo seu sucedâneo patrimonial"(4).

A jurisdição não poderia agir de outro modo, eis que eventual indenização não equivale ao imensurável valor da vida e da saúde humanas, objetivo final da importação dos testes.

Peca, entretanto, a Digene do Brasil, quando argumenta que a gradativa redução do número de produtos cuja importação requer anuência prévia do Ministério da Saúde está em sintonia com uma "salutar" pressão do comércio internacional, com vista à diminuição das barreiras não-tarifárias à

(4) Cassio Scarpinella Bueno, "Liminar em Mandado de Segurança". São Paulo: Revista dos Tribunais, 1999, p. 78. 
importação. É bem verdade que no âmbito da integração econômica regional, isto é, no seio do Mercosul, poderia ser elaborada uma política comunitária de saúde pública. Esse conhecimento mútuo, aliado a um planejamento coerente de ações comuns em seara sanitária justificaria a flexibilização de exigências reciprocas.

Sublinhe-se, contudo, que a saúde pública configura nítida e legítima exceção ao desmantelamento tarifário, mesmo num "mercado interior",(5) em que a integração encontra-se em impressionante grau de avanço, como é o caso da União Européia - UE. À guisa de exemplo, enquanto os artigos 28 e 29 do Tratado da União Européia - TUE proíbem toda e qualquer restrição quantitativa à exportação e à importação, além das medidas de efeito equivalente, o subseqüente artigo 30 do TUE assegura a possibilidade de estabelecer:

"proibições ou restrições à importação, exportação ou trânsito justificada por razões (...); de proteção da saúde e da vida das pessoas e animais ou de preservação das plantas". (6)

No mesmo sentido, o Título XIII do TUE, intitulado "Saúde Pública", determina em seu artigo 152, entre outras medidas, que

"na definição e execução de todas as políticas e ações da Comunidade será assegurado um elevado nível de proteção da saúde".(7)

Via de conseqüência, a UE desenvolve até mesmo uma política nutricional comum, ${ }^{\left({ }^{8}\right)}$ produzindo uma "tecnologia" de cooperação que seria tão bem vinda na América do Sul, cuja desnutrição em grande escala mostra claramente que nossa prioridade não é a inserção comercial internacional, mas sim a consolidação de nossas democracias e de uma cooperação que vise a eliminar a internacionalmente indigna exclusão.

De outra parte, numa breve referência ao processo global de liberalização do comércio, orquestrado pela Organização Mundial do Comércio OMC, é preciso reconhecer que uma das posições políticas defendidas no âmbito dessas negociações é a liberalização incondicionada do comércio, que se mostra possível especialmente nos países em via de desenvolvimento. No entanto, há outras posições, entre elas a da UE, que defendem a manutenção de exceções ao livre comércio, especialmente vinculadas à saúde e ao meio ambiente, lançando um fascinante debate sobre o "princípio da precaução".(9) Trata-se, grosso modo, da possibilidade de impedir a circula-

(5) Eis que a expressão mercado comum, embora ainda utilizada no Brasil para referir a UE, já foi superada pelo processo mais profundo de eliminação das fronteiras, denominado mercado interior.

(6) União Européia. "Tratados Consolidados". Luxemburgo: OPOCE, 1997, p. 51.

(7) Ibid., p. 108.

(8) Ver Comissão Européia, "Livro Branco sobre a segurança dos alimentos", COM (1999) 719 final, Bruxelas, 12 de janeiro de 2000.

(9) Ver Christine Noiville, "Principe de précaution et OMC - Le cas du commerce alimentaire", Journal de Droit International, 2. 2000; Comissão Européia, Communication de la Commission su 
ção de produtos cuja nocividade não foi comprovada, mas a respeito da qual há suspeitas.

Finalmente, após a análise de uma decisão in limine corretamente fundamentada, é de se perguntar porque o Brasil ou os seus parceiros no Mercosul não fabricam tão importantes testes clínicos. O sentido do Mercosul consiste precisamente em resolver os numerosos problemas comuns dos seus sócios, através da cooperação. Em matéria de saúde pública, como de resto em quase todos os domínios, com exceção do puro comércio, a atuação do Mercosul é irrelevante. Para que o bloco venha a beneficiar um espectro mais amplo da cidadania platina, é preciso que ele supere o impasse comercial interno em que se encontra, voltando-se para a promoção de políticas comuns viáveis e que respondam aos anseios da população. A saúde pública espera atenta uma merecida atenção e urgentes investimentos.

le recours au principe de précaution, $\operatorname{COM}(2000) 1$, disponivel em: <europa.eu.int/comm/ off/com/ health_consumer/precaution.htm>; e Maruyama, W.-H., "A new pilar of WTO: sound science", The International Lawyer, vol. 32, n. 3. 